This is an electronic reprint of the original article. This reprint may differ from the original in pagination and typographic detail.

Author(s): Vähäsantanen, Katja; Saarinen, Jaana; Eteläpelto, Anneli

Title: Between school and working life: Vocational teachers agency in boundary-crossing settings

Year: $\quad 2009$

Version:

Please cite the original version:

Vähäsantanen, K., Saarinen, J., \& Eteläpelto, A. (2009). Between school and working life: Vocational teachers' agency in boundary-crossing settings. International Journal of Educational Research, 48 (6), 395-404. doi:10.1016/j.ijer.2010.04.003 Retrieved from http://www.elsevier.com/wps/find/journaldescription.cws_home/491/descr...

All material supplied via JYX is protected by copyright and other intellectual property rights, and duplication or sale of all or part of any of the repository collections is not permitted, except that material may be duplicated by you for your research use or educational purposes in electronic or print form. You must obtain permission for any other use. Electronic or print copies may not be offered, whether for sale or otherwise to anyone who is not an authorised user. 


\section{Between school and working life: vocational teachers' agency in boundary-crossing settings}

Katja Vähäsantanen, Jaana Saarinen \& Anneli Eteläpelto

University of Jyväskylä, Finland

Katja Vähäsantanen *

University of Jyväskylä, Department of Educational Sciences, P.O. Box 35, 40014 Jyväskylä, Finland

Tel: +358-14-260 1679

Fax: +358-14-260 1661

Email: katja.vahasantanen@jyu.fi

Jaana Saarinen, University of Jyväskylä, Department of Teacher Education, P.O. Box 35, 40014 Jyväskylä, Finland

E-mail: jaana.a.saarinen@jyu.fi

Anneli Eteläpelto, University of Jyväskylä, Department of Educational Sciences, P.O. Box 35, 40014 Jyväskylä, Finland

E-mail: anneli.k.etelapelto@jyu.fi

* Corresponding author

\section{Abstract}

This paper investigates agency among vocational teachers with reference to boundary-crossing between school and working life. Our study utilised interviews with sixteen Finnish vocational teachers. Adopting a narrative analysis approach, we found that the teachers had a variety of forms of exercising agency in terms of decisions deliberately taken, and the discourse and actions following these decisions. These forms were: (i) restricted agency, (ii) extensive agency, (iii) multifaceted balancing agency, (iv) situationally diverse agency, and (v) relationally emergent agency. The exercising of agency was intertwined with the main resources and constraints emerging from the teachers' sense of their professional self, their awareness of their relationships to workplace personnel, and their views of the professional tasks determined by the school. Depending on its nature and direction, agency appears to create diverse conditions for teachers' productive work in boundary-crossing settings, for developing education and for remaking the work practices of workplaces. 


\section{Introduction}

Recent years have seen radical changes in workplace practices. In many professions these have involved new forms of cooperation and the breakdown of traditional boundaries both inside and between work organisations. This has meant that employees - including the vocational teachers examined in this paper - have had to move in and out of different work environments, build personal networks across organisational boundaries, and work with partners from different professions, drawing on resources that may be distributed across settings (Edwards, 2005; Kirpal, 2004; Tuomi-Gröhn \& Engeström, 2003). Nevertheless, this "growth area" in contemporary working life has not received the attention it deserves (Billett, 2006a; Edwards, 2005), and we still know relatively little about how individuals exercise their agency and become competent actors when they work at the boundaries of work settings.

Moreover, those studies that have in fact examined boundary-crossing between work organisations and communities have focused mainly on learning. Fuller and Unwin (2004) argue that when organisations create expansive learning environments, where individuals engage in multiple communities and boundary-crossing situations outside and within work organisations, they also provide a basis for the integration of personal and organisational development. Wenger (1998) sees the role of a border crosser (i.e. a person who is a member of many communities of practice) as innovative, since such a person can introduce elements into a practice from other communities. The role of as border crosser is, however, extremely challenging, since the person is usually forced to work without power, in the marginal areas of communities. Only with time can individuals move from the periphery to the centre of communities, through learning to act and think according to the existing culture of the community (Lave \& Wenger, 1991). This kind of theorising does not explain precisely the dynamics of creative learning; moreover, it underplays the position of the active subject, tending to view the community of practice as a repressive site. The reality may be more complex: recent discussion suggests that although workplace settings have particular practices and 
traditions that shape individuals' work activities and social interactions, within the workplace individual agency plays a key role in learning, in engagement with work, and in remaking culturally developed practices (Billett, 2006a, 2008; Hodkinson, Biesta \& James, 2008; Vähäsantanen \& Billett, 2008). Thus, we would suggest that it is essential to focus on individual agency if we are to understand how individuals work and participate in social settings outside the boundaries of their work organisations.

The present study examines vocational teachers' agency in boundary-crossing settings, as exercised between school and working life. In Finland, initial vocational education and training has traditionally been school-based. However, it was extensively transformed at the national level at the turn of the millennium, and further transformations have since taken place at local level. The aim has been to break down the traditional separation between schools and workplaces and to introduce a system for students' workplace learning (Filander, 2007; Virtanen, Tynjälä \& Stenström, 2008). Currently, vocational qualifications in all fields include at least six months (20 credits out of 120 credits) of workplace learning; this takes place in authentic work environments outside the schools. The workplaces are in both the private and the public sector, and have a varying number of employees.

The developments in vocational education have also transformed the tasks of vocational teachers. Increasingly, they must work outside the school and cooperate with workplace personnel. Their work includes organising, guiding and evaluating students' workplace learning, finding workplaces for the students, supporting those workplace employees who will act as trainers during students' workplace learning, and informing workplace personnel on the (reformed) vocational education system (Filander, 2007; Vähäsantanen \& Eteläpelto, 2009). Since the vocational teachers move back and forward on the boundaries of school and work, they can be seen as occupying an important position as mediators between schools and workplaces. This makes it important to investigate how these teachers exercise their agency and to determine the kinds of resources and constraints that are related to the exercise of agency when they work in boundary-crossing settings. 
In this paper, we report on data obtained from interviews with vocational teachers. We then discuss key questions concerning the conditions for exercising agency, many of which have implications for teachers' work, for developing education and for refashioning practices in working life.

\section{Theoretical perspectives on agency}

Our understanding of subject and agency is informed by post-structural approaches, which see the subject as active and self-creating within processes of becoming, acting in work practices and interacting with other actors, despite being bound up with especially power relations and discursive practices (Davies, 2000; Fenwick, 2006). Thus, we would not agree with authors (e.g. Rose, 1999) who paint a picture of passive workers, entirely subjected to the practices of organisational management. We also utilise certain basic ideas from socio-cultural approaches in our assumption that the way subjects think and act is always imbued by socio-cultural structures and conditions (e.g. Wertsch, Tulviste, \& Hagstrom, 1993). Nevertheless, in our view, socio-cultural perspectives do not, on the whole, sufficiently encompass the ways in which people are active within social practices and discourses. Despite recognising the role of externalisation, the individual is seen as subservient to the social. All in all, we understand subjects as active actors who are entangled with the web of socio-cultural practices and discourses in which they move and speak. Our theoretical stance thus highlights the importance of both the individual and the social for individual actions performed within boundary-crossing settings (see also Billett, 2008).

Broadly speaking, in education, agency is seen as the capability of persons to make intentional choices, and to act on these choices in ways that make a difference in their lives (e.g. Martin, 2004; Watkin, 2005). In accordance with this, Fenwick and Somerville (2006) observe that agency can be understood as the individual's internal resource, fashioned as the will, intention, and capability to act. For Billett (2008) individuals' agency refers, broadly, to their intentional actions. However, these authors do not see agency merely as free will or as the freedom to do and act in a totally unrestrained way, regardless of social and structural circumstances. In accordance with this, 
Ahearn (2001) emphasises the importance of social circumstances for human intentions, thoughts and actions, defining agency as "the socioculturally mediated capability to act". With these definitions in mind, individual agency is here understood as individuals' deliberate activities in work settings and interactions; these are manifested as decisions by subjects on their own activities, and as actions based on these decisions. This means that agency is exercised within the opportunities and constraints of social circumstances. In addition to this, agency is here seen as intertwining with subjects' professional interests and values, their sense of self, their views of themselves in relation to workplace practices, and their ways of understanding their relationship with the world (Billett, 2006a; Eteläpelto \& Saarinen, 2006; Fenwick, 2006).

Agency can be manifested in actions of various kinds - discursive (Ahearn, 2001), cognitive, social, or embodied (Clegg, 2006; Fenwick \& Somerville, 2006). Hence, agency can be analysed by focusing on (i) actions in social practices and discourses, and (ii) the meaning and purpose of these actions. According to some authors (e.g. Ahearn, 2001), it is especially important for researchers to ask people for their own interpretations of their activities, and not simply to observe the activities. Furthermore, the exercise of agency can vary over time and circumstances, and more so for some participants than others (Billett, 2006a). This suggests that in studying agency we should focus on individuals in different settings, and over time.

As regards agency, individuals have a range of subject positions available to them in the workplace. They can choose to accept, ignore or resist social suggestions and offered positions, and they can also create new positions (Billett, 2006b; Fenwick \& Somerville, 2006; Weedon, 1997). An adopted position brings a structure of expectations and obligations, and provides possibilities for and limitations on acting and speaking (Phillips, 2006). This means that different subject positions will illustrate various ways of being an individual (Weedon, 1997). For example, teachers and students have particular positions in discourses, and there are traditional rules for their activities and interactions (Phillips, 2006). Similarly, we can suggest that there are particular limitations and opportunities pertaining to working as a vocational teacher in boundary-crossing situations. Within 
work practices, becoming an active agent is based on the subject's reflective awareness of his/her position in the work community. On the basis of this, the subject can enter into appropriate activity orientations and make conscious choices concerning his/her actions and strategies (Phillips, 2002). In addition to this, the subject's agency is a matter of finding the possibilities which can expand - or break down - previous hegemonies, closed meanings, and habitual positioning (Fenwick, 2006). In such cases, new social practices can emerge and individual transformation can begin.

The features of agency mentioned above raise significant issues for research. To what extent are subjects free to decide on their actions, and to what extent are they constrained by the social settings in which they work? What kinds of resources support the exercise of agency, and what are the essential limitations on its exercise? How can individuals change the social practices and the subject positions offered to them in the workplace? Discussion concerning these questions is essential if we are to understand how subjects engage in work settings, or if we wish to facilitate their work and support the transformation of social practices. With these considerations in mind, the study reported in this paper aimed to address the following questions: (i) What forms of agency do vocational teachers exercise in the course of their work in boundary-crossing settings? (ii) What are the main resources and constraints related to the different forms of agency exercised by vocational teachers in boundary-crossing settings?

\section{Data collection and analysis}

The data for the study were obtained via open-ended narrative interviews conducted by the first author. In 2006, sixteen vocational teachers from the same institution were interviewed (ten men and six women, aged 31-57, with teaching experience ranging from 4 to 30 years). They taught in different study programmes belonging to various fields of initial vocational education and training. Finnish vocational teachers have a vocational qualification from their own vocational field, and have at least three years of work experience in that field. 
We understand interviewing as a narrative process entailing knowledge production. In this interactive process, both the interviewer and the interviewee are active participants (Holstein \& Gubrium, 2003; Riessman, 2008). In the interviews for the present study, the following issues were discussed: (i) the vocational teachers' professional development and career, (ii) the teachers' sense of professional identity, and the nature of their work, (iii) the continuous educational reforms and the current curriculum reform, (iv) the work community and organisation, (v) hopes and expectations for the future. Thus, through narratives, the interviewees could interpret themselves and their experiences, other actors in their work situations, and a variety of events in their professional lives. The interviews varied in length from 75 minutes to 125 minutes. (For further information on the participants and the interviews, see Vähäsantanen \& Eteläpelto, 2009; Vähäsantanen \& Billett, 2008).

At the centre of the narrative analysis came episodes and situations from the teachers' boundary-crossing settings. Boundary-crossing settings were understood as involving those visits to workplaces that were related in particular to students' workplace learning. At the start of the analysis, each interview was read carefully several times. We noticed that the accounts of the boundary-crossing settings emerged across interviews, and were intertwined with other topics. Because of this, we identified and focused on those parts of the interviews in which teachers described themselves and their activities in boundary-crossing settings, including the interpretations they gave for their decisions and actions (Riessman, 2008). After this data-extraction, we summarised each interview (i.e. we created short illustrative accounts from all the original interviews). In order to protect the anonymity of teachers, we sought to conceal teachers' individual backgrounds (including age, teaching experience and vocational field) in these accounts.

After compiling the summaries, we re-read each of them as a whole, focusing on how teachers exercised their agency, and the ways in which resources and constraints were related to their exercise of agency (Lieblich, Tuval-Mashiach \& Zilber, 1998). This made it possible to analyse variations in the exercise of agency in relation to the different episodes within individual accounts. 
In the next stage of the analysis, we searched for differences and similarities concerning teachers' agency between individual accounts. As a result, we identified five different ways of exercising agency, representing variations across the teachers interviewed. In addition, we elaborated the main resources and constraints that might be related to these ways of exercising agency. The five categories we identified appeared to represent the variation in the data comprehensively, since all the teachers could be placed fairly unambiguously in one of these categories. In addition, we could place more than one teacher in each category. Of course, even in the same category there was no individual teacher who was totally identical to another teacher.

\section{Findings}

This section describes the five forms of agency identified and the main resources and constraints related to these forms. The forms were as follows: (i) restricted agency, (ii) extensive agency, (iii) multifaceted balancing agency, (iv) situationally diverse agency, and (v) relationally emergent agency. Below, each form, plus related resources and constraints, will be illustrated from the accounts of particular teachers. After these illustrative cases, we shall summarise the findings concerning the research questions.

\subsection{Restricted agency}

When Aaron carried out his professional responsibilities in boundary-crossing settings, it was his awareness of his relationship to the workplace personnel that particularly determined his way of making decisions and acting as a teacher. In other words, Aaron had a clear opinion on the kinds of relationships that existed between workplace personnel and teachers, and the kinds of actions that were acceptable from the viewpoint of workers. According to Aaron, a teacher must act with due humility: "A teacher must adopt a sensible style when entering and being in the workplace. Just giving advice and being critical is totally wrong, you won't get anywhere with that. You really have to go to the workplace 'cap in hand'. That's the basic principle - that you know how to behave in 
the right way and give them respect." This would mean that teachers cannot be critical or question existing workplace practices. Aaron's stance was meek and uncritical, since his purpose for actions was to avoid conflicts in workplaces. According to Aaron, by showing respect and avoiding criticism one can avoid upsetting workplace staff or provoking conflicts that could lead to workplaces refusing to receive students at all. This would be extremely harmful for the current vocational education system. In addition to this, Aaron indicated that because the workplace staffmembers' professional competencies were better than his own competencies within the vocational field, there were no reasons for him to advise staff on their own ways of doing things.

Aaron also said that teachers should not intervene in the practices taught to students by workplace trainers, even if they might be wrong or unsuitable. On the other hand, he found that he could advise workers on how to guide students' learning at work, because they were willing to accept this kind of information. However, in such a case, workplace trainers need to be guided gently, without giving too much direct instruction. Otherwise, as Aaron reported, "the workers would kick the teachers out of the workplaces, saying 'Who are you to come here and give advice?'"

By being respectful and seeking harmony with the workplace employees, Aaron's purpose of avoiding conflict was fulfilled. However, such an approach created constraints in carrying out the tasks determined by the school. As an example of this, Aaron described a situation in which he was supposed to discuss a student's workplace learning with the workplace trainer and the student: "There was a terrible rush and there I was, waiting four hours [to do what was required]. Then I had to leave and the workers didn't have time for anything else, except to say hello. Apart from that they were just scurrying around all over the place." This illustrates how Aaron avoided disturbing workplace personnel by just waiting without demanding attention, even if he was supposed to carry out his tasks. There was clearly a problem of a lack of recognition of the teacher's function on the part of the workers. In addition, Aaron reported that in order to co-operate successfully with the workplace employees, teachers needed the ability to provide them with information they really 
needed from the school. Teachers also needed social skills, and overall capabilities to work with strangers from different professions.

Nowadays vocational teachers carry out many of their work responsibilities outside the school. For example, the teachers must find workplaces for the students' workplace learning periods, and inform workers about how they should conduct workplace instruction. Aaron reported that these tasks were difficult for teachers. Often, the workplace personnel were not particularly interested in guiding students' learning; after all, they do not get any extra payment for doing so, and the guidance interrupts their actual work. In addition to this, the school institution does not offer enough working hours for these tasks, nor does it offer sufficient support. According to Aaron, the lack of support in matters of informing workplaces about curriculum reform and eliciting workplace co-operation can complicate the work of the teachers and weaken their motivation:

"Everybody thinks that teachers have enormous influence on things... However, the teacher's influence is fairly limited when it's a question of discussing matters with the manager of a large company. It's just like talking to the wind, most of them simply don't care ... Because of this, there should be proper provision of information to the workplaces from the administration of the vocational institution. Then it would be a lot easier for a teacher to go into the workplaces... It's tough if the entire responsibility is loaded onto the teacher. The teacher can talk all he likes in the workplaces but it doesn't make any difference. Then teachers get frustrated, start to skimp things, look for the easy way out."

From this one sees how - especially in large companies - the teachers' unequal relationships with the workplace staff and managers, and the lack of support from the school, can complicate the teachers' professional duties. However, in the end Aaron had found that co-operation with the staff had enabled him to learn new skills within the vocational field.

\subsection{Extensive agency}


When Vivian worked outside the school, she decided on her own activities according to her own professional interests and beliefs, and on that basis, acted as a teacher in the way she saw fit. In fact, her professional interests were in line with the professional tasks determined by the school, and Vivian saw them as extremely meaningful. Vivian took it as her primary purpose to inform workplace personnel about the students' professional development, and about the professional competencies which should be taught by personnel during students' workplace learning. She had found such work to be important, since, in her opinion, workers often lack knowledge concerning the vocational education system and students' professional development. Furthermore, she was concerned in case - without her input - the workplace trainers might not give proper support to a student's learning; or else that they might require too high a level of achievement in relation to the student's age and capabilities. In following up these professional interests and purposes she was an energetic actor, seeing herself as an important link between working life and the educational system. She was proud of her work and valued it greatly.

Within the current vocational educational and training system, students are fairly young when they do their workplace learning. According to Vivian, it is common for representatives of working life to criticise severely the weak professional competencies of the students. When she receives such comments, she is a vigorous advocate of the educational system, seeing no need for excessive humility, and making no particular purpose to achieve a harmonious interaction. On the contrary, she may seek to shift the blame for the situation onto working life personnel themselves, as in the following example:

"I'm always in conflict with the people in working life ... They don't understand the development of vocational education even if they have partly been given the responsibility for the training, which was what they themselves specifically wanted. I've told some employers when they've been coming out with harsh criticism of students' poor professional capabilities, that now, in the amount of students' workplace learning we've got to the situation that the employers had previously wanted and demanded." 
Although Vivian had actively pursued her own professional interests and purposes, she was aware of workplace employees' opinions concerning the teachers and the students. She said that the employees often patronised the teachers, believing them to be incompetent. They could take the view that nothing could be learned from either the teachers or the students, and that teachers should be more or less invisible in the workplace. However, this did not constrain Vivian. In fact, she exercised agency almost without regard to social suggestions and relationships, ignoring the attitudes of workplace personnel and the limitations that people from the workplace might have wished to set on her activities. This can also be seen in the next episode reported by her. She describes how she intervened in the workplace, because she felt that the student she had come to observe was carrying out the task wrongly. When Vivian reminded the student about the rights and wrongs of the matter, it became clear that the student had been given incorrect instruction by the workplace trainer. In this situation, Vivian recognised an opportunity to put the trainer and the employer right. As consequence of this, they reflected on their practices and recognised their unsuitability. In this way, both the student's professional competencies and the practices of the workplace staff were developed through Vivian's intervention:

"... [in our field] people talk a great deal about the level of hygiene, and there is a requirement that the cutlery should be washed in the kitchen and taken to the customers with maximum hygiene. And then yesterday I saw in a workplace how one of our students was pressing one's thumb on all the spoons when the student was putting them on the tray. I said to the student 'Do you remember what we've said about handling cutlery? You can't leave your thumbprint on the eating surface of every piece of cutlery.' The manager and the workplace trainer looked at each other and said that they always did it that way. I said, 'Lets' think, can you be sure that your thumb is clean?' I asked if there would be any chance of organising it in some other way. Then they noticed that there was a clear breakdown in procedure and said that they themselves had something to learn..." 
This shows how teachers' active interventions in such situations can improve existing work practices, and perhaps also shape workplace personnel's attitudes to teachers, when they understand that they can learn something from the teachers. Vivian had found such collaboration and knowledge-sharing to be beneficial for both students and workplace staff - and also for herself, because she had been able to gain new insights and information on current working life, and hence adapt her teaching to the students in the school. In addition to this, the interaction with the staff had enriched her work; she had found simply working in the school to be somewhat boring, and unsuited to her temperament. However, according to Vivian, the ability to function as she had done required good competencies within the vocational field. She had these as resources in co-operating with employees, and in taking firm action overall.

\subsection{Multifaceted balancing agency}

Thomas's activities were closely intertwined with his professional interests, and with a desire to realise these interests actively at the interface between school and working life. His main interest was in developing his own study programme so that it would be more closely linked to the needs of working life. More broadly, he wanted to create bridges between working life and the educational system, seeking to connect the needs of working life with the curriculum of the school. In order to realise his professional interests and purposes, Thomas had voluntarily asked workplace personnel about their experiences, and about their opinions on what should be included in vocational education. On this basis, he had been able to develop his teaching and the study programme in his vocational field. He had also received positive feedback from the workers about this work - not least because he had been one of the first to seek their opinions.

In addition to this, Thomas had worked on a voluntary basis in the same workplaces where his students had been during their workplace learning periods. Indeed, he had spent a lot of unpaid extra time on chatting to the representatives of working life, spending breaks with them, etc. According to Thomas, by such means, and through practical activities in the workplace, teachers 
can show that they are just ordinary people, and that they have some professional competencies within the vocational field in question:

"My co-operation with some companies has started very well, and it has been highly dependent on the fact that I spent some days working there. They see that I'm quite a normal human being who can do their tasks to some extent. Then they begin to talk to me about certain issues, and I can tell them about certain issues from the school context; and gradually our conversation and thinking starts to move in the same direction. I believe that this kind of collaboration can bring these two worlds closer together."

This episode also shows that close cooperation between workplace employees and teachers can make it easier to get information from working life, to transfer information from the school to the workplaces, to exchange experiences between employees and teachers, and to bring the views of both parties closer to each other.

Although Thomas had a strong focus on his professional interests and purposes, at the same time his activities were based on an awareness of his relationships with the employees, and also on his own previous experience in the business world. Hence, his purpose was to be a collaborative actor in working life. Thomas thought that teachers needed to accept their relationships to the employees and to have a degree of humility in order to work successfully; or as he put it: "Yes, I know that a teacher can be unacceptably active in the workplace. I'm quite willing to stay in my own compartment without trying to be too active." He went on to say that teachers cannot force workplace staff to act according to the school's ways of proceeding, and he described his own cooperation with staff in the terms of listening and careful collaboration. Having been in the business world himself, he was aware that teachers could disturb routines and cause extra work. In view of this, his purpose was to take account of the realities of workplaces, through asking questions and helping the representatives of working life through his own activities: "I've worked as entrepreneur myself, and at that time I had students in my company, so I do know that side of things. Now when 
I'm a teacher I've asked the managers, supposing they had fifteen persons [i.e. the students plus a teacher] what it is that they would like us to do. So that's always been my point of departure."

Through his individual actions, Thomas had thus expanded the vocational teacher's traditional role via boundary-crossing settings, creating new practices between school and work - going further than merely carrying out his compulsory professional tasks as determined by the school. Thomas had also created certain new practices: he had organised workplace staff to carry out teaching duties in the school (informally, when appropriate), because these were individuals with highly specialised professional expertise in the vocational field. All in all, Thomas saw his participation in working life as advancing his continuous professional development, while giving him some time away from the hectic atmosphere of the school. However, he experienced his work as wearisome from time to time. He was aware that the cooperation between school and working life had been totally dependent on teachers' personal relations with the workplaces and on their enthusiasm. Teachers were being obliged to create cooperative relationships with workplaces, but without receiving adequate help, resources or support from the school. To carry out the necessary tasks, he himself had been forced to use up some of his own free time.

\subsection{Situationally diverse agency}

In boundary-crossing settings, Wilhelm acted differently across different situations. This meant that he was both an active and a passive actor, mainly on the basis of how he understood his professional tasks and his relationships with workplace personnel.

On the one hand, Wilhelm felt that the tasks that the school had ordered him to perform outside the school were extremely important and worth doing well. He had clear opinions on the kinds of active measures this entailed, bound up with his awareness of the relationships between employees and teachers. According to Wilhelm, employees did not respect teachers, thinking that the teachers had poor competencies and little understanding of working life: "Employees tend to look down on teachers to some extent, to think that a mere teacher doesn't know anything about the 
real world and real work." In addition to this, Wilhelm was aware of the boundaries between workplace employees and teachers: "That's just the way it is, teachers are teachers, and employees are employees."

Wilhelm's awareness of employees' opinions did not lead him to adopt the unequal position offered to him. On the contrary, he thought that he had to create a more equal relationship with the workplace trainers and to gain their respect if he was to carry out his professional duties successfully. This purpose could be achieved by demonstrating good professional skills within the vocational field, through both words and actions, and by speaking the same language as the employees. Sometimes it has been enough for him simply to act and speak from his own experiences in order for the trainers to realise that he knew what he was talking about. However, quite often it had been necessary for him to actively demonstrate his professional skills and his mastery of workplace discourse. As Wilhelm put it:

"In working life teachers must speak the language of the employees. It's the only way that they will treat teachers as equals... Teachers can increase their own respect and employees will listen to them properly, when their talk and their habitus show that they really know what real work is. I've seen this happen often. I've told some employees - it has irritated me so much, when they talk to me like a child - that I really am familiar with working life and the things they have to do, because I've done the same work for quite a long time myself. But sometimes I don't need to say it; it's enough that I speak from my own experience, so that they notice it from what I say. After that, the person's attitude towards me changes completely... It might sound that I have personal reasons for my activities, because I'm irritated. However, it is strongly related to the fact that if I am not convincing, I can't carry out my duties. The worker looks at me and talks to me differently - his level of trust is totally different, when he recognises that I really know a lot about what we're talking about and have good experience of it..." 
This shows how Wilhelm's good professional competencies within the vocational field were a resource for achieving a more equal relationship with the workplace staff. Although Wilhelm already had good professional skills, he further believed the best aspect of a teacher's work to lie in the fact that acting in workplaces promotes continuous professional development.

On the other hand, in certain respects Wilhelm was a fairly passive actor. He said that he did not see it as his professional duty to develop working life or workplace practices. Because of this, he did not question existing work practices; nor did he give advice to the employees, even if he felt that the practices of workplaces should be developed, and that he would have the competencies to bring this about. He sought harmony, not wishing to irritate employees by giving advice. In Wilhelm's words: "I could say that I could bring new practices to each workplace. However, on no account am I going to start offering such practices. I don't want people to get the feeling that I'm coming here to straighten them out. I expect and encourage students to be the ones who will introduce new practices”. Wilhelm assumed that he could not fulfil his professional tasks properly if he provoked conflicts in working life. He further reported that none of the employees had asked him to help or advise them. Thus, it seemed that although he had shown his professional competencies through what he said and did, he had not achieved the kind of professional status within the working life community that would bring about change.

\subsection{Relationally emergent agency}

When Peter worked in boundary-crossing settings, he was always energetic in carrying out his responsibilities as a teacher. For example, he always took an active role when workplace trainers were actually guiding students, believing that his professional duty lay in supporting trainers in such tasks. However, Peter sometimes felt that it was difficult to carry out these tasks, since the school institution did not offer sufficient working time for them.

Otherwise he acted differently over time, because his activities were shaped by how he saw his relation to the employees. If he was not familiar with them, he was fairly cautious in his dealings 
with them. For example, he did not intervene in the employees' own practices, even if he thought that their work practices were in some way defective. He wished to avoid conflict, putting the matter thus:

"I think twice before I start to advise workers on how they should carry out their own duties. And I could say it depends on whether the worker is someone I know from before. I mean, there's really very few of us who like to be advised just like that, about how the work should be done. You'll certainly have problems if you do that."

Nevertheless, Peter became really active in relation to workplace personnel, and willing to question their ways of doing things, once he had got to know them. In such a case he did not just take on the teacher's traditional role, acting only in relation to his narrowly-defined professional duties; he also took on the role of an expert, helping workplace staff and developing practices in working life. Clearly, the prerequisite for this expanded role was a relationship of trust with workers, and in addition, recognition by both the teacher and the workers of their own positions. The following quotation illustrates this:

"...we co-operate closely with about twenty small companies, let's say that I advise them on technical issues several times a week and so on. For me, it's no problem to go to these companies, and there I can say pretty quickly to a worker, 'Hi, why are you doing this way, there's no point in that.' I'm not afraid to say it, because we know each other... But first I need to construct what you could call a connection with the worker, and both of us, teacher and worker, must be aware of our own position."

In this case, Peter was talking about small companies. One can surmise that it may be easier for teachers to create good relationships with workplace staff in smaller companies than in larger ones.

However, Peter highlighted the fact that teachers cannot create equal relationships just by letting matters drift on. The teachers have to demonstrate their professional knowledge through words and deeds. Without this, according to Peter, the representatives of working life will regard teachers with suspicion. Hence, good professional competencies seem to be an important resource 
for achieving respect and taking firm action. Correspondingly, Peter also reported that his cooperation with the employees had further improved his professional skills; without such cooperation he would lose touch with working life and with his own vocational field. Furthermore, Peter said that when he was on familiar terms with the workplace staff, they would consult him. As time went by, he and the staff would talk informally, share experiences concerning professional issues, and - in relevant respects - criticise the educational and organisational reforms planned by the school.

\subsection{The five forms of exercising agency, plus related resources and constraints}

The forms of exercising agency can be summarised as follows. The teachers who exercised restricted agency acted humbly and passively, taking on the socially accepted role of teachers. Their decisions and actions were mainly guided by their awareness of their unequal relationship with the workplace personnel, and to some degree, by a sense of a lack of highly specialised professional competencies within the vocational field. In such a case, they did not create any conflicts in working life (and indeed, conflict-avoidance was their purpose), but nor were they able to carry out all their professional tasks adequately. In the case of extensive agency, the teachers decided on their actions and realised them, mainly on the basis of their professional interests and purposes. They were active participants, ignoring any supposed inequalities between teachers and workers, fulfilling their professional duties, and developing the practices of the workplaces. Their good professional competencies within the vocational field also supported these kinds of actions. Those teachers who exercised multifaceted balancing agency took an active and collaborative role, because they wanted to find a fit between their professional intentions and the employees' needs. Thus, their deliberate acts were broadly based on their professional interests and competencies, their previous work experiences, and their views of their relationship with the employees. This enabled them to create new ways of acting as a teacher, and novel working practices between the school and 
the work. They favoured a sharing relationship with the employees, one that could also prepare the ground for developing education.

In the case of situationally diverse agency, the teachers were both active and passive actors, depending on the situation. This variety was intertwined with their views of their professional tasks, and their awareness of the relationships between workplace staff and teachers. On the one hand, the teachers acted energetically as teachers and were active in demonstrating their professional competencies, with a view to re-negotiating their relationships with the staff and thus fulfilling their tasks successfully. Their good professional competencies were a further resource in these activities. On the other hand, they acted passively in the sense that they drew back from developing the practices of the workplace. The teachers who exercised relationally emergent agency acted on the basis of how they viewed themselves in relation to their professional tasks and to the employees. These teachers were constantly active in carrying out their professional responsibilities. In addition to this, when their relationships with the employees became more familiar over time, they became more active in terms of developing the employees' practices. Their active role was further promoted by their good professional competencies.

To sum up the answers to our research questions, we identified five forms of exercising agency: (i) restricted agency, (ii) extensive agency, (iii) multifaceted balancing agency, (iv) situationally diverse agency, (v) relationally emergent agency. The diverse forms of exercising agency were intertwined individually with the teachers' sense of their professional self (i.e. the teachers' perceptions of their professional interests, their professional competencies and their previous work experiences). Agency was also linked to how they understood their relations with workplace personnel, and how they viewed themselves in relation to the professional tasks determined by the school.

\section{Concluding discussion}


As the findings from our study demonstrate, there were considerable differences among vocational teachers in terms of how they exercised their agency, and how their agency was related to the different resources and constraints - which were both individual and social in nature. It appeared that all the teachers exercised agency actively in terms of making decisions, based on their individual interpretation of the resources and constraints pertaining to their work. However, their deliberately-taken decisions led to various embodied and discursive activities. All in all, we would argue that all the teachers exercised a certain degree of agency regardless of the nature and direction of their practical activities, given that their practical actions were consciously undertaken, and grounded on deliberate choices. In accordance with Ahearn (2001), we would also highlight that in studies concerning agency it is vital to focus also on individuals' interpretations, including the explanations they provide regarding their decisions and activities. Otherwise, it will be impossible to reach an elaborated understanding of the complex nature of agency. This study further illustrates that the teachers might exercise agency in a more or less uniform manner through different situations and over time - or else in a varying manner, depending on the time that elapsed and on how the situation developed. Hence, we would tend to agree with Billett (2006a), who has noted that the exercise of agency can vary over time and over situations. This same phenomenon can be seen in the cases of relationally emergent agency and situationally diverse agency presented in this paper.

The findings indicate that vocational teachers are entangled with different institutional tasks, social practices and power relationships (cf. Billett, 2008; Fenwick, 2006). First of all, the school organisation determines particular work tasks and responsibilities for teachers, which they must fulfil in boundary-crossing settings. In addition to this, the teachers' agency is interwoven with their relationships with the representatives of working life. The teachers' accounts revealed that there are traditional relationships and boundaries between teachers and employees in terms of being members of different professions, and that teachers are basically not equal with workplace personnel. Furthermore, teachers are often seen by employees as to some degree incompetent, vocationally 
speaking. In the teachers' work, it seems to be important to be aware of these boundaries, positions and relationships (Phillips, 2002), and of the ways in which they create limitations on and possibilities for teachers' activities. However, social suggestions and relationships do not comprehensively shape teachers' thinking, acting and working, since teachers can also utilise their individual backgrounds, interests and purposes in their intentional activities. In boundary-crossing settings, the vocational teachers' work could thus be described as a matter of creatively achieving a situationally appropriate balance between the schooling organisation, working life and the teacher's professional self, based on his/her reflexive awareness of different interests and expectations. This might imply that the teacher's work could be explained through consideration of the relations between personal and social contributions.

In terms of what it means to exercise agency, the findings revealed that some teachers ignored or reshaped traditional boundaries between the representatives of working life and teachers, by expanding or breaking habitual positioning (Fenwick, 2006). In so doing they developed education and the practices of workplace personnel, creating new ways of acting as teachers, and constructing new practices between working life and school. However, not all the teachers exercised agency in a way that would make a difference to the existing practices of workplaces (e.g. Watkin, 2005), or to pre-existing relationships and boundaries. This happened mainly because teachers saw it as necessary to avoid conflicts with employees in order to carry out their tasks successfully. This might indeed be a totally appropriate strategy for the teachers, depending on the opinions of the employees and the culture of the workplace. On the other hand, the avoidance of conflicts removed the possibility of remaking social practices or developing practices in the workplace, and sometimes this was also an obstacle for the teachers in carrying out the professional tasks determined by the school. On the basis of our findings, we would emphasise that the different forms of exercising agency create different conditions for teachers' productive work in boundary-crossing settings, and further, for developing education and re-making the work practices of workplaces. This means that the nature and direction of individuals' agency is essential for the way in which individuals carry 
out their socially determined work tasks. Furthermore, the contribution of and direction of individual agency is central to the shaping of practices and relationships in working life (Billett, 2008).

The findings seem to imply that the school, workplaces and teachers can benefit if teachers cross the boundaries between school and working life (cf. Fuller \& Unwin, 2004). From the viewpoint of the schooling organisation, teachers' boundary-crossing can be of value for the purposes of developing education and for matching education better with the needs of working life. Boundary-crossing can bring new insights to the school from working life. Moreover, through collaboration with working life, the teacher can also learn about current competencies within the vocational field and receive information from workplaces. However, from the viewpoint of the teacher, this can require a huge personal contribution. Some of the teachers interviewed had used their free time for creating relationships and for collecting information from working life, in order to do their work successfully and to develop schooling. Of course, the benefits are not just one-way - within the workplaces, work practices can be developed on the basis of the teacher's knowledge. However, it cannot be taken for granted that the co-operation between teachers and workplace staff will be innovative from the viewpoint of developing working practices. The teachers do not always dare to question the employees' practices or advise on more suitable ways of working, even when they have the competencies and knowledge to do so.

The changes in vocational teachers' work require them increasingly to cross boundaries between the school and working life, and to work in networks with multiple partners from working life. It appears that in this situation teachers need to have good professional competencies within the vocational field, and that they must demonstrate them in words and deeds. This may make it possible to create or re-negotiate a more equal relationship with workplace staff, and help teachers to better carry out their professional responsibilities. In addition to this, teachers should be able to understand people from different professions and "speak the same language" as the employees. On the contrary, some teachers find that the best way of working in boundary-crossing settings involves 
adopting a respectful, humble and uncritical style of interaction. Even if vocational teachers need various kinds of personal skills and knowledge to work in boundary-crossing settings, the size of work organisations may impose particular requirements for good collaboration. Furthermore, we would emphasise that teachers should be better supported by the school in carrying out their work tasks. Generally speaking, the co-operation with working life seemed to depend on the teacher's individual efforts, being constructed mainly through the teacher's personal contacts and contributions. Many of the interviewees were enthusiastically involved in their work but the fulfilment of their professional tasks and the creating of relationships with employees was hard work, in the absence of clear support from the school.

This study revealed something of the nature and form of vocational teachers' agency at the interface of school and work. However, the data were limited in terms of comprising only what teachers mentioned concerning experiences and episodes from boundary-crossing settings. In the future, the exercise of agency through embodied and discursive activities could be studied by observations in authentic situations, with interviews as a follow-up. Due to the nature of our data and our intention to protect the anonymity of teachers, this study did not focus precisely on how the background of the teachers or the workplace personnel (including e.g. vocational field, age and working experience) shaped their co-operation. Nor could we elaborate in any detail how the particular practices and culture of the workplaces are related to teachers' agentic actions, since teachers talked more about their relationships to workplace personnel than about the practices of the workplaces. We can assume that particular workplace affordances are related to these relationships, but on the basis of our data we can only suggest (as mentioned earlier) that the size of the workplace seems to have an influence on these relationships. Further examination is required to elaborate these aspects. Further examination is also needed to investigate how vocational teachers exercise collective agency together with working life partners in social networks outside the school. 


\section{Acknowledgements}

The study presented in this paper was supported by the Academy of Finland (Project no. 111184, "Professional identity in working life communities") and by The Finnish Graduate School in Education and Learning (FiGSEL). We wish to thank the vocational teachers we interviewed for sharing their individual experiences, and the anonymous referees for their comments on the manuscript. We would also like to thank Donald Adamson, who polished the language of the paper.

\section{References}

Ahearn, L. M. (2001). Language and agency. Annual Review of Anthropology, 30(1), 109-37.

Billett, S. (2006a). Work, change and workers. Dordrecht: Springer.

Billett, S. (2006b). Work, subjectivity and learning. In S. Billett, T. Fenwick \& M. Somerville (Eds.), Work, subjectivity and learning: Understanding learning through working life (pp. 1-20). Dordrecht: Springer.

Billett, S. (2008). Learning through work: Exploring instances of relational interdependencies. International Journal of Educational Research, 47(4), 32-47.

Clegg, S. (2006). The problem of agency in feminism: A critical realist approach. Gender and Education, 18(3), 309-324.

Davies, B. (2000). (In)scribing body/landscape relations. Walnut Greek: Alta Mira Press.

Edwards, A. (2005). Relational agency: Learning to be a resourceful practitioner. International Journal of Educational Research, 43(3), 168-182.

Eteläpelto, A., \& Saarinen, J. (2006). Developing subjective identities through collective participation. In S. Billett, T. Fenwick \& M. Somerville (Eds.), Work, subjectivity and learning: Understanding learning through working life (pp. 157-177). Dordrecht: Springer. 
Fenwick, T. (2006). Escaping/becoming subjects: Learning to work the boundaries in a boundaryless work. In S. Billett, T. Fenwick \& M. Somerville (Eds.), Work, subjectivity and learning: Understanding learning through working life (pp. 21-36). Dordrecht: Springer.

Fenwick, T., \& Somerville, M. (2006). Work, subjectivity and learning: Prospects and issues. In S. Billett, T. Fenwick \& M. Somerville (Eds.), Work, subjectivity and learning: Understanding learning through working life (pp. 247-265). Dordrecht: Springer.

Filander, K. (2007). Deconstructing dominant discourses on vocational education. In R. Rinne, A. Heikkinen \& P. Salo (Eds.), Adult education - Liberty, fraternity, equality? Nordic views on lifelong learning? (pp. 261-274). Helsinki: Finnish Educational Research Association.

Fuller, A., \& Unwin, L. (2004). Expansive learning environments: Integrating personal and organisational development. In H. Rainbird, A. Fuller \& A. Munro (Eds.), Workplace learning in context (pp. 126-144). London: Routledge.

Hodkinson, P., Biesta, G., \& James, D. (2008). Understanding learning culturally: Overcoming the dualism between social and individual views of learning. Vocations and Learning: Studies in Vocational and Professional Education, 1(1), 27-47.

Holstein, J. A., \& Gubrium, J. F. (2003). Active interviewing. In J. F. Gubrium \& J. A. Holstein (Eds.), Postmodern Interviewing (pp. 67-80). Thousand Oaks: Sage.

Kirpal, S. (2004). Researching work identities in a European context. Career Development International, 9(3), 199-221.

Lave, J., \& Wenger, E. (1991). Situated Learning: Legitimate peripheral participation. Cambridge: University Press.

Lieblich, A., Tuval-Mashiach, R., \& Zilber, T. (1998). Narrative research: Reading, analysis and interpretation. London: Sage.

Martin, J. (2004). Self-regulated learning, social cognitive theory, and agency. Educational Psychologist, 39(2), 135-145. 
Phillips, D. K. (2002). Female preservice teachers' talk: Illustrations of subjectivity, visions of 'nomadic' space. Teachers and Teaching: Theory and Practice, 8(1), 9-27.

Phillips, K. R. (2006). Rhetorical maneuvers: Subjectivity, power and resistance. Philosophy and Rhetoric, 39(4), 310-332.

Riessman, C. K. (2008). Narrative methods for the human sciences. Thousand Oaks: Sage.

Rose, N. (1990). Governing the soul: The shaping of the private self (2nd ed.). London: Routledge.

Tuomi-Gröhn, T., \& Engeström, Y. (Eds.). (2003). Between school and work: New perspectives on transfer and boundary-crossing. Oxford: Elsevier.

Virtanen, A., Tynjälä, P., \& Stenström, M.-L. (2008). Field-specific educational practices as a source for students' vocational identity formation. In S. Billett, C. Harteis \& A. Eteläpelto (Eds.), Emerging perspectives of workplace learning (pp. 19-34). Rotterdam: Sense Publishers.

Vähäsantanen, K., \& Billett, S. (2008). Negotiating professional identity: Vocational teachers’ personal strategies in a reform context. In S. Billett, C. Harteis \& A. Eteläpelto (Eds.), Emerging perspectives of workplace learning (pp. 35-48). Rotterdam: Sense Publishers.

Vähäsantanen, K., \& Eteläpelto, A. (2009). Vocational teachers in the face of a major educational reform: Individual ways of negotiating professional identities. Journal of Education and Work, $22(1), 15-33$.

Watkin, C. (2005). Classrooms as learning communities. London: Routledge.

Weedon, C. (1997). Feminist practice and poststructuralist theory (2nd ed.). Oxford: Blackwell.

Wenger, E. (1998). Communities of practice: Learning, meaning and identity. Cambridge: University Press.

Wertsch, J., Tulviste, P., \& Hagstrom, F. (1993). A sociocultural approach to agency. In. A. Forman, N. Minick \& A. Stone (Eds.), Contexts for learning sociocultural dynamics in children's development (pp. 336-357). New York: Oxford University Press. 